\title{
Toxomerus duplicatus Wiedemann, 1830 (Diptera: Syrphidae) preying on Microtheca spp. (Coleoptera: Chrysomelidae) larvae
}

\author{
Sturza, VS. ${ }^{a *}$, Dequech, STB. ${ }^{b}$, Toebe, M. ${ }^{a}$, Silveira, TR. ${ }^{a}$, Cargnelutti Filho, A. ${ }^{c}$ and Bolzan, A. ${ }^{b}$ \\ aprograma de Pós-graduação em Agronomia, Universidade Federal de Santa Maria - UFSM, Avenida Roraima, \\ Bairro Camobi, 1000, CEP 97105-900, Santa Maria, RS, Brazil \\ ${ }^{\text {b}}$ Departamento de Defesa Fitossanitária, Centro de Ciências Rurais, Universidade Federal de Santa Maria - UFSM, \\ Avenida Roraima, Bairro Camobi, 1000, CEP 97105-900, Santa Maria, RS, Brazil

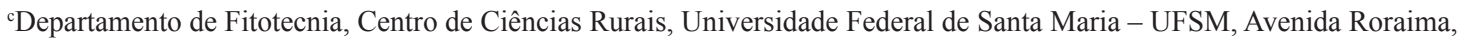 \\ Bairro Camobi, 1000, CEP 97105-900, Santa Maria, RS, Brazil \\ *e-mail: vsturza27@yahoo.com.br
}

Received: March 19, 2013 - Accepted: May 7, 2013 - Distributed: August 31, 2014

\begin{abstract}
Microtheca spp. (Coleoptera: Chrysomelidae) are insect pests primarily related to Brassicaceae crops. In the State of Rio Grande do Sul (RS), southern Brazil, they are found on forage turnip, Raphanus sativus L. var. oleiferus Metzg., which is commonly grown during fall/winter seasons. This work reports the predation of Microtheca spp. larvae by Toxomerus duplicatus Wiedemann, 1830 (Diptera: Syrphidae) larvae, on forage turnip crop, in Santa Maria, RS. This register provides new information about Microtheca spp. natural enemies in Brazil, which might be a new option for integrate pest management of these species.
\end{abstract}

Keywords: Brassicaceae, Raphanus sativus L. var. oleiferus Metzg., Predator.

\section{Toxomerus duplicatus Wiedemann, 1830 (Diptera: Syrphidae) predando larvas de Microtheca spp. (Coleoptera: Chrysomelidae)}

\begin{abstract}
Resumo
Microtheca spp. (Coleoptera: Chrysomelidae) são insetos-praga relacionados principalmente às culturas da família Brassicaceae. No Estado do Rio Grande do Sul (RS), no sul do Brasil, são encontrados no nabo forrageiro, Raphanus sativus L. var. oleiferus Metzg, comumente cultivado no outono/inverno. Este trabalho relata a predação de larvas de Microtheca spp. por larvas de Toxomerus duplicatus Wiedemann, 1830 (Diptera: Syrphidae), em nabo forrageiro, em Santa Maria, RS. Este registro oferece nova informação sobre os inimigos naturais de Microtheca spp. no Brasil os quais podem ser uma nova opção para o manejo integrado dessas espécies.
\end{abstract}

Palavras-chave: Brassicaceae, Raphanus sativus L. var. oleiferus Metzg., Predador.

\section{Introduction}

Microtheca spp. (Coleoptera: Chrysomelidae) are insect pests primarily related to Brassicaceae crops and its occurrence is reported from South America, where they are indigenous, to southeastern United States, especially Microtheca ochroloma Stal, 1860 and Microtheca semilaevis Stal, 1860 (Manrique et al., 2010). In Brazil these species are found in different Brassicaceae crops (Menezes Júnior et al., 2005; Farinha et al., 2009; Poncio et al., 2010) and their presence commonly results in severe defoliation, due to the feeding habits of both larvae and adults, which are based on consumption of leaf tissue. This makes Microtheca spp. species very important pests, especially to organic farmers who have few options to control infestations satisfactorily, including M. ochroloma (Poncio et al., 2010) and M. semilaevis. Consequently considerable losses in production are verified, especially because the low value of the products on the market due to visual depreciation.

In the state of Rio Grande do Sul, southern Brazil, larvae of these insects are also found on forage turnips, Raphanus sativus L. var. oleiferus Metzg., which is commonly grown on areas after grain production, such as maize and soybean, during fall/winter seasons, where it is an option for rotation crops schemes, due to its capacity of covering the soil and cycling chemical elements, mainly phosphor and nitrogen (Ohland et al., 2005). Besides the dry matter losses, the presence of these beetles on forage turnip crop areas raises the concern of possible establishment as alternative sites for both feeding and reproduction by Microtheca spp. since spraying is not usually employed by farmers on this crop. 
The maintenance of natural enemies in crop areas is one of the basic aspects to integrate pest management and, thus, searching for natural enemies of Microtheca spp. in forage turnip crops is basic to determine what options for controlling these insect pests are present. In Brazil, Poncio et al. (2010) reported a Pentatomidae, predator of both larvae and adults of M. ochroloma, found on a Chinese cabbage (Brassica chinensis L.) crop area and no other natural enemies are reported in the country so far.

This work reports the predation of Microtheca spp. larvae by Toxomerus duplicatus Wiedemann, 1830 (Diptera: Syrphidae) larvae, on forage turnip crop.

\section{Material and Methods}

An experiment was carried out at experimental area of "Departamento de Fitotecnia" - Universidade Federal de Santa Maria (UFSM), latitude $29^{\circ} 42^{\prime}$ S, longitude $53^{\circ} 49^{\prime} \mathrm{W}$ and $95 \mathrm{~m}$ height above the sea level. Forage turnip seedling was made on June $10^{\text {th }}, 2010$ with final plant density of 150 plants. $\mathrm{m}^{-2}$ and a used area of 0.25 ha. Fertilisation was made according to soil chemical analysis and no chemical products were sprayed.

Fourteen samples were made from emergency to flowering (from June $24^{\text {th }}, 2010$ to $09^{\text {th }}$ September, 2010, respectively). During each sample, fifty plants, chosen randomly, were evaluated totalling 700 evaluated plants. All leaves and stems were examined for presence of Microtheca spp. larvae and predators. The insects were collected and maintained in plastic cups of $100 \mathrm{~mL}$ with a small piece of leaf, and transported to the "Laboratório de Entomologia, Departamento de Defesa Fitossanitária" - UFSM. Syrphidae were individually kept in plastic cups lined with filter paper, humidified with distillate water. All Syrphidae preyed on Microtheca spp. larvae, offered on a daily basis. To ensure great Syrphidae survivorship and save Microtheca spp. individuals for providing adults (necessary to proper identification) aphids were offered together until the Syrphidae reach pupal stage. Maintained Microtheca spp. larvae were fed with forage turnip leaves until reach the pupal stage. Afterwards both Syrphidae and Microtheca spp. adults were sent to specialists for proper identification.

\section{Results and Discussion}

All beetle larvae were M. ochroloma or M. semilaevis. Eight Syrphidae larvae were collected on August $19^{\text {th }}$ (2 larvae); August $23^{\text {rd }}$ (1 larva); September $04^{\text {th }}$ (3 larvae) and September $2^{\text {nd }}$ (2 larvae) dates. Syrphidae voucher are deposited at Departamento de Defesa Fitossanitária, Universidade Federal de Santa Maria. Despite all insects having reached pupal stage, three adults were obtained; one was identified as Toxomerus duplicatus Wiedemann, 1830 and the other two were of the genus Toxomerus Wiedemann. Those were not possible to identify to species level due to changes in colour patterns which are intrinsic and used for proper identification. It was caused by long time storage in alcohol.
There are over 150 species of Toxomerus of which nearly 143 are distributed in the Neotropical Region (Marinoni et al., 2007). T. duplicatus is recorded for southern Brazil in the states of Paraná and Santa Catarina (Marinoni et al., 2007).

Where known, Toxomerus larvae are predators, and preys commonly are among groups Fulgoroidea, Cercopoidea, Cicadelloidae, Aleyrodoidea, Aphidoidea, Coccoidea (Hemiptera) and Thysanoptera (Thompson, 1982). Prey preferences of $T$. duplicatus are not known.

The predation of Microtheca spp. larvae by T. duplicatus in Brazil is new and represents an important option for the forage turnip and also for other Brassicaceae crops, especially where M. ochroloma and M. semilaevis larvae occur. Syrphidae larvae are known as important natural enemies of aphids in different crops (Oliveira et al., 2003; Ghahari et al., 2008), including greenhouses (Pimentel, 2007), due to their capacity of consuming great amounts of insects during its developmental time (Marinoni et al., 2007). Furthermore, adults perform an important role as pollinators of different vegetable species (Morales and Köhler, 2008). Thus, further studies such as those related to T. duplicatus biology and also multiplication techniques are necessary to investigate the possibility of using this predator as a biological control agent for both M. ochroloma and M. semilaevis larvae in different Brassicaceae crops.

The presence of Syrphidae larvae was observed in the final crop cycle period, near flowering, where availability of food resources to adults, such as pollen and nectar, were greater. This suggests that, during the whole period of Microtheca spp. occurrence, the use of border areas might increase $T$. duplicatus population, providing benefits to adult insects such as supplementary food resources, moderate microclimate and shelter (Venzon et al., 2005).

This register provides additional knowledge about the natural enemies of Microtheca spp. in Brazil, which might be a new option to integrate into pest management of M. ochroloma and/or M. semilaevis in Brassicaceae crops.

\section{Acknowledgements}

The authors thank Dr. Luciano de Azevedo Moura, from the Departamento de Zoologia, Universidade Federal do Rio Grande do Sul, for M. semilaevis and M. ochroloma identification and Mirian Nunes Morales for Syrphidae identification. Also, to the Conselho Nacional de Desenvolvimento Científico e Tecnológico and Coordenação de Aperfeiçoamento de Pessoal de Nível Superior for fellowships.

\section{References}

FARINHA, LA., MENEZES JÚNIOR, O., VENTURA, MU. and MIKAMI, AY., 2009. Occurrence of Microtheca punctigera (Achard) and Microtheca semilaevis Stal in five hosts in the field. Arquivos do Instituto Biológico, vol. 76, no. 3, p. 365-371.

GHAHARI, H., HAYAT, R., TABARI, M. and OSTOVAN, H., 2008. Hover flies (Diptera: Syrphidae) from rice fields and round grasslands of Northern Iran. Munis Entomology and Zoology, vol. 3 , no. 1 , p. 275-284. 
MANRIQUE, V., MONTEMAYOR, CO., CAVE, RD., SKVARCH, EA. and SMITH, BW., 2010. Effect of straw mulch on populations of Microtheca ochroloma (Coleoptera: Chrysomelidae) and ground predators in forage turnip Brassica rapa in Florida. The Florida Entomologist, vol. 93, no. 3, p. 407-411. http://dx.doi. org/10.1653/024.093.0314.

MARINONI, L., MORALES, MN. and SPALER, I., 2007. Chave de identificação ilustrada para os gêneros de Syrphinae (Diptera, Syrphidae) de ocorrência no sul do Brasil. Biota Neotropica, vol. 7, no. 1, p. 145-160. http://dx.doi.org/10.1590/ S1676-06032007000100019.

MENEZES JÚNIOR, AO., MIKAMI, AY., IDE, AK. and VENTURA, MU., 2005. Feeding preferences of Microtheca punctigera (Achard) (COLEOPTERA: CHRYSOMELIDAE) for some Brassicaceae plants in multiple-choice assays. Scientia Agricola, vol. 62, no. 1, p. 72-75. http://dx.doi.org/10.1590/S0103-90162005000100014.

MORALES, MN. and KÖHLER, A., 2008. Comunidade de Syrphidae (Diptera): diversidade e preferências florais no Cinturão Verde (Santa Cruz do Sul, RS, Brasil). Revista Brasileira de Entomologia, vol. 52, no. 1, p. 41-49. http://dx.doi.org/10.1590/ S0085-56262008000100008.

OHLAND, RAA., SOUZA, LCF., HERNANI, LC., MARCHETTI, ME. and GONÇALVES, MC., 2005. Culturas de cobertura do solo e adubação nitrogenada no milho em plantio direto. Ciência e Agrotecnologia, vol. 29, no. 3, p. 538-544. http://dx.doi. org/10.1590/S1413-70542005000300005.

OLIVEIRA, MRV., AMANCIO, E., LAUMANN, RA. and GOMES, LO., 2003. Natural enemies of Bemisia tabaci (Gennadius) B biotype and Trialeurodes vaporariorum (Westwood) (Hemiptera: Aleyrodidae) in Brasilia, Brazil. Neotropical Entomology, vol. 32, no. 1, p. 151-154. http://dx.doi.org/10.1590/S1519566X2003000100023.

PIMENTEL, D., 2007. Encyclopedia of Pest Management. New York: CRC Press. 784 p.

PONCIO, S., DEQUECH, STB., STURZA, VS., LISSNER, RAD., PERLIN, LF., ROSALINO, PK. and RIBEIRO, LP., 2010. Primeiro relato de Stiretrus decastigmus no Brasil predando Microtheca ochroloma. Ciência Rural, vol. 40, no. 5, p. 1203-1205. http:// dx.doi.org/10.1590/S0103-84782010005000069.

THOMPSON, FC., 1982. Syrphidae. In HURLBERT, SH. and VILLALOBOS-FIGUEROA, A. Aquatic Biota of Mexico, Central America and the West Indies. California: San Diego State University. p. 464-465.

VENZON, M., ROSADO, MC., EUZÈBIO, DE. and PALLINI, A., 2005. Controle biológico conservativo. In: VENZON, M., PAULA JÚNIOR, T.J. and PALLINI, A. (Eds.). Controle alternativo de doenças e pragas. Viçosa: EPAMIG. p. 1-22. 